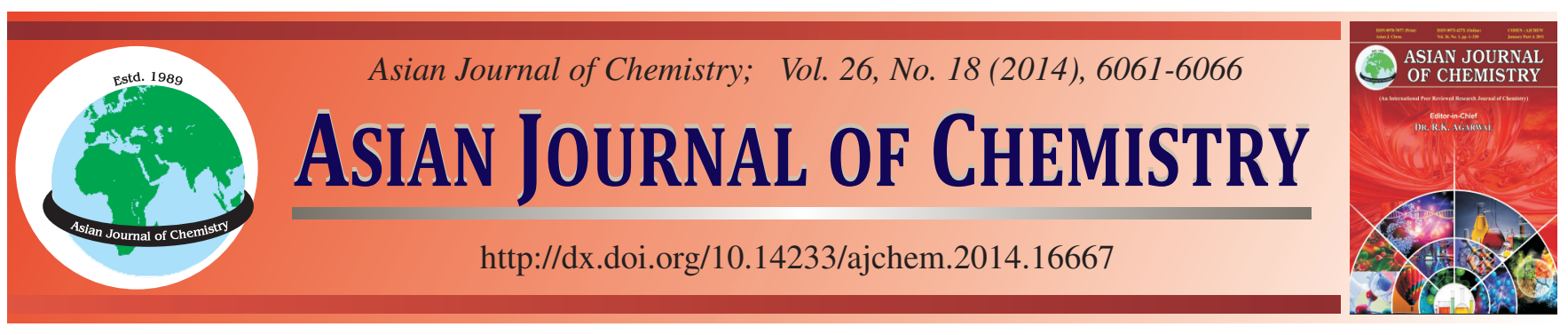

\title{
A Comparative Study on Characterization of 12-Tungstophosphoric Acid Cesium Salt Depending on Synthesis Methods
}

\author{
EliF ÖDEs AkBAY* and GÜlberk Demir
}

Anadolu University, Department of Chemical Engineering, Eskisehir, 26470, Turkey

*Corresponding author: E-mail: eodes@anadolu.edu.tr

Received: 9 November 2013;

Accepted: 4 April 2014;

Published online: 1 September 2014;

AJC-15854

12-Tungstophosphoric acid cesium salt, $\mathrm{Cs}_{2.5} \mathrm{H}_{0.5} \mathrm{PW}_{12} \mathrm{O}_{40}$, exhibits high catalytic activity for various kinds of acid-catalyzed reactions.
This excellent catalytic effect of $\mathrm{Cs}_{2.5} \mathrm{H}_{0.5} \mathrm{PW}_{12} \mathrm{O}_{40}$ is attributed to its strong acidity, hydrophobicity, unique pore structure, etc. In this
study, the methods published in the literature were modified by monitoring the aging, atmospheric drying-vacuum drying and calcination,
addition rate of $\mathrm{Cs}_{2} \mathrm{CO}_{3}$ solution to 12-tungstophosphoric acid solution to enhance the surface properties of Cs-12-tungstophosphoric acid
such as the surface area and porosity. The characteristic of the synthesized Cs-12-tungstophosphoric acid were obtained by the XRD,
FTIR, SEM, TG-DTG, particle distribution and crystallite size and the results were compared with the finding in literature. The each
modified methods have different effect on the BET surface area and porosity. The sample coded by 01G50V showed the highest surface
area with $4.5 \mathrm{~nm}$ pore diameteramong synthesized 12-tungstophosphoric acid cesium salt.

Keywords: 12-Tungstophosphoric acid, Cesium salt, Impregnation methods.

\section{INTRODUCTION}

Catalysis by heteropoly acids (HPAs) and related polyoxometalate compounds is a field of increasing importance and attracting increasing attention worldwide, in which many new and exciting developments are taking place in both research and technology ${ }^{1}$. Heteropoly acids are generally used as catalysts in commercially important process such as hydrocracking, hydrogenation and isomerization. However, heteropoly acid is not preferred as a liquid catalyst in industrial applications, because there will be required additional processes such as purification of the products. Hence, the synthesis of the salt of heteropoly acid catalysts are insoluble in water and in organic solvents are very important ${ }^{2}$.

Heteropoly acids of various heterogeneous catalysts have drawn attention due to their unique features such as welldefined structure, Bronsted acidity, high proton mobility, the ability to exchange electrons ${ }^{3,4}$. As a heteropoly acid, 12tungstophosphoric acid, $\mathrm{H}_{3} \mathrm{PW}_{12} \mathrm{O}_{40}$, is known as a strong acid and it is considered within the class of super acid ${ }^{5}$. The substitution of protons such as $\mathrm{Cs}^{+}, \mathrm{K}^{+}, \mathrm{Ag}^{+}$and $\mathrm{NH}_{4}{ }^{+}$can enhance the porosity and surface area as well as the insolubility.

12-Tungstophosphoric acid cesium salt, $\mathrm{Cs}_{2.5} \mathrm{H}_{0.5} \mathrm{PW}_{12} \mathrm{O}_{40}$, has high surface area thus it exhibits high catalytic activities for various kinds of acid-catalyzed reactions ${ }^{6-8}$. This excellent catalytic effect of $\mathrm{Cs}_{2.5} \mathrm{H}_{0.5} \mathrm{PW}_{12} \mathrm{O}_{40}$ is attributed to the strong acidity, hydrophobicity, unique pore structure, etc. ${ }^{9}$. It was reported that many reactions were effectively catalyzed by $\mathrm{Cs}_{2.5} \mathrm{H}_{0.5} \mathrm{PW}_{12} \mathrm{O}_{40}$ in a solid-liquid reaction system. $\mathrm{Cs}_{2.5} \mathrm{H}_{0.5} \mathrm{PW}_{12} \mathrm{O}_{40}$ is an interesting candidate for preference, as a 'water-tolerant' catalyst because of its insolubility in organic and aqueous media, in contrast with $\mathrm{H}_{3} \mathrm{PW}_{12} \mathrm{O}_{40}{ }^{10}$.

Therefore there are available studies about this catalyst on a micro-scale synthesis, characterization and catalytic activity in reactions in literature. Among these studies, the study by Okuhara et al. ${ }^{11}$ is very important to review acidic cesium salt synthesis and its micro-structure. They synthesized the catalyst by impregnation technique at different ratio of cesium and characterized it by NMR, XRD, SEM. They concluded that among cesium salts, $\mathrm{Cs}_{\mathrm{x}} \mathrm{H}_{3-\mathrm{x}} \mathrm{PW}_{12} \mathrm{O}_{40}(\mathrm{x}=1,2,2.5$ and 3), $\mathrm{Cs}_{2.5} \mathrm{H}_{0.5} \mathrm{PW}_{12} \mathrm{O}_{40}$ was to be the most effective catalyst because of having highest activity.

In the other study, to evaluate the effects of the content of cesium, the catalyst was prepared having different cesium content, $\mathrm{Cs}_{\mathrm{x}} \mathrm{H}_{3-\mathrm{x}} \mathrm{PW}_{12} \mathrm{O}_{40}(\mathrm{x}=1,2,2.5$ and 3$)$ and characterization was performed using FTIR, XRD and P-MAS NMR. It was shown that the distribution of proton and cesium ion in the salts structures is nearly homogeneous and surface acidity increases sharply as the cesium content increases and it reaches the maximum in $\mathrm{Cs}_{2.5} \mathrm{H}_{0.5} \mathrm{PW}_{12} \mathrm{O}_{40}$ salt. On the other hand, it was also shown that $\mathrm{Cs}^{+}$ions are completely settled in $\mathrm{Cs}_{3} \mathrm{PW}_{12} \mathrm{O}_{40}$ salt no showing Bronsted acidity ${ }^{12}$. 
Therefore, $\mathrm{Cs}_{2.5} \mathrm{H}_{0.5} \mathrm{PW}_{12} \mathrm{O}_{40}$ salt called Keggin-type tungstophosphates, possess super acidity and effective in many acid-catalyzed reactions such as alkylation of aromatics ${ }^{13,14}$, skeletal isomerization of $n$-butane ${ }^{15-17}$, hydrolysis of esters in excess water ${ }^{18}$, hydration of olefins in a solid-water reaction system $^{19}$, esterification of palmitic acid and transesterification of tributyrin ${ }^{20}$.

The aim of this study is to determine the best conditions of impregnation method for synthesis of 12-tungstophosphoric acid cesium salt (Cs-TPA). The methods published in the literature were modified by making some change the aging, atmospheric drying-vacuum drying, calcination and addition rate of $\mathrm{Cs}_{2} \mathrm{CO}_{3}$ solution to 12-tungstophosphoric acid solution to enhance the physical properties of salt such as surface area and porosity. The other properties of the synthesized Cs-TPA were also determined by the XRD, FTIR, SEM, TG-DTG, particle distribution and crystallite size and the results were compared with the finding of literature.

\section{EXPERIMENTAL}

The chemicals used in the preparation of catalysts, 12tungstophosphoric acid hydrate $\left(\mathrm{H}_{3} \mathrm{PW}_{12} \mathrm{O}_{40} \times \mathrm{H}_{2} \mathrm{O}\right)$ and cesium carbonate $\left(\mathrm{Cs}_{2} \mathrm{CO}_{3}\right)$ were purchased from Merck and Alfa Aesar, respectively. Deionized water was used though out in experiments.

Synthesis of Cs-TPA: $0.1 \mathrm{M}$ aqueous solution of $\mathrm{Cs}_{2} \mathrm{CO}_{3}$ and $0.08 \mathrm{M}$ aqueous solution of 12-tungstophosphoric acid hydrate were prepared. Then, $20 \mathrm{~cm}^{3}$ of aqueous solution of $\mathrm{Cs}_{2} \mathrm{CO}_{3}$ was added to $20 \mathrm{~cm}^{3}$ of aqueous solution of 12-tungstophosphoric acid hydrate with a constant rate of about 1 and $0.1 \mathrm{~cm}^{3} / \mathrm{min}$ at room temperature, under vigorous stirring. The other parameters used at each addition rate of $\mathrm{Cs}_{2} \mathrm{CO}_{3}$ solution is shown in Table-1.

\begin{tabular}{|c|c|c|c|}
\hline \multicolumn{4}{|c|}{ TABLE-1 } \\
\hline No. & Sample name & $\begin{array}{l}\text { Addition rate } \\
(\mathrm{mL} / \mathrm{min})\end{array}$ & Synthesis method \\
\hline \multirow{2}{*}{1} & 01G50E & 0.1 & \multirow{2}{*}{$\begin{array}{l}\text { Aging over night drying with } \\
\text { drying-oven at } 50^{\circ} \mathrm{C}\end{array}$} \\
\hline & $1 \mathrm{G} 50 \mathrm{E}$ & 1.0 & \\
\hline \multirow{2}{*}{2} & 01G50V & 0.1 & \multirow{2}{*}{$\begin{array}{l}\text { Aging over night drying with } \\
\text { vacuum oven at } 50^{\circ} \mathrm{C}\end{array}$} \\
\hline & $1 \mathrm{G} 50 \mathrm{~V}$ & 1.0 & \\
\hline \multirow{2}{*}{3} & 01G110V & 0.1 & \multirow{2}{*}{$\begin{array}{l}\text { Aging over night drying with } \\
\text { vacuum oven at } 110^{\circ} \mathrm{C}\end{array}$} \\
\hline & $1 \mathrm{G} 110 \mathrm{~V}$ & 1.0 & \\
\hline \multirow{2}{*}{4} & $01110 \mathrm{~V}$ & 0.1 & \multirow{2}{*}{$\begin{array}{c}\text { Drying with vacuum oven } \\
\text { at } 110^{\circ} \mathrm{C}\end{array}$} \\
\hline & $1110 \mathrm{~V}$ & 1.0 & \\
\hline \multirow{2}{*}{5} & 01110V473K & 0.1 & \multirow{2}{*}{$\begin{array}{l}\text { Drying with vacuum oven at } \\
110^{\circ} \mathrm{C} \text { calcination at } 200^{\circ} \mathrm{C}\end{array}$} \\
\hline & $1110 \mathrm{~V} 473 \mathrm{~K}$ & 1.0 & \\
\hline
\end{tabular}

Characterization of Cs-TPA: The crystallinity and the phase purity of synthesized samples were analyzed by X-ray diffraction (XRD) patterns using X-ray diffractometer (Rigaku Rind 2000, Japan) and $\mathrm{CuK} \alpha\left(1.54 \mathrm{~A}^{\circ}\right)$ radiation $(30 \mathrm{kV}-40$ $\mathrm{mA}$ ). The scanning was done from $2 \theta=80^{\circ}$ to $2 \theta=5^{\circ}$ at a rate of $2^{\circ} \mathrm{min}^{-1}$. FTIR studies of the catalysts were conducted by using a Bruker IFS-66 single channel Fourier transform spectrophotometer, pellet in $\mathrm{KBr}$ and a measuring range of $400-4000 \mathrm{~cm}^{-1}$. Scanning electron microscopy (SEM) results were obtained on the Zeiss Supra 50 VP Microscope with 20 $\mathrm{kV}$ accelerating voltage. Termogravimetry analysis were performed under dry air, using $80 \mathrm{mg}$ samples and heating rates $10{ }^{\circ} \mathrm{C} / \mathrm{min}$. The studied temperature range $20-900{ }^{\circ} \mathrm{C}$. The particle size distribution in water was analyzed by laser diffraction method using a Malvern Hydro 2000G analyzer. TG-DTG measurements of sample were carried out using Netzsch Sta 409 PC/PG thermal analyzer. The BET (BrunauerEmmett-Taller) specific surface area was obtained from $\mathrm{N}_{2}$ adsorption-desorption isotherm measured at $77 \mathrm{~K}$ in an automatic adsorption apparatus (ASAP2020; micrometritics). Prior to measurement, samples were degassed at $100^{\circ} \mathrm{C}$ for about $2 \mathrm{~h}$.

\section{RESULTS AND DISCUSSION}

All synthesized Cs-TPA and TPA have been characterized by using XRD patterns due to basic analytical techniques. Diagrams obtained from the analysis is shown in Fig. 1.

Fig. 1 shows that the XRD patterns of all synthesized 12tungstophosphoric acidsalts is in the $2 \theta$ range of $5-80^{\circ}$ and all Cs-TPAs are identical with each other. The patterns for the Cs-TPA exhibits the characteristic lines of TPA structure and
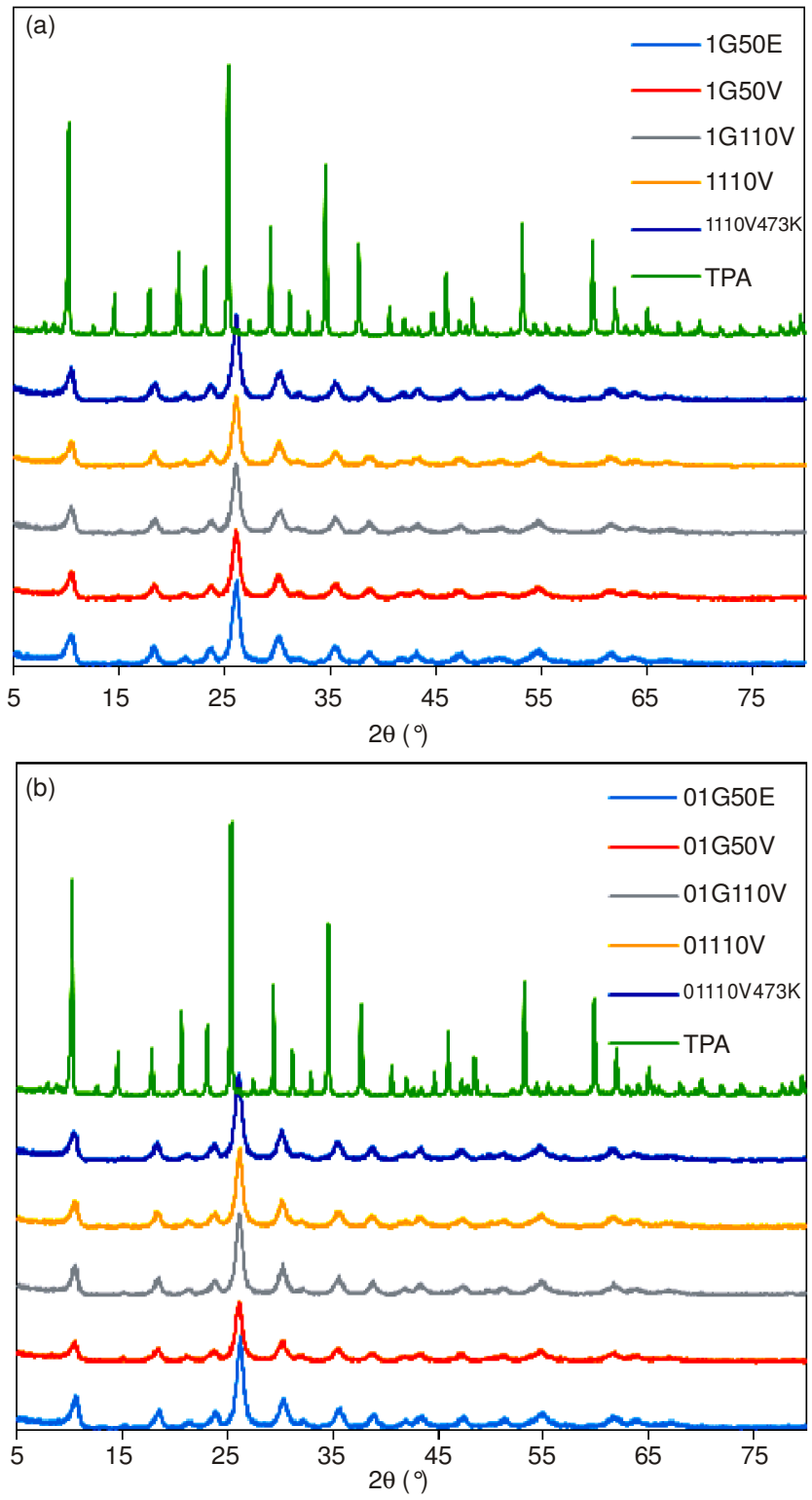

Fig. 1. XRD diagrams for (a) synthesized catalysts with $1 \mathrm{~mL} / \mathrm{min}$ addition rate (b) synthesized catalysts with $0.1 \mathrm{~mL} / \mathrm{min}$ addition rate 
are in agreement with published data ${ }^{21,22}$. It can be also seen that the location of XRD peaks of Cs-TPA is very similar to that of pure TPA indicating that the Cs salt has similar crystalline structure as the pure TPA. However, the main peaks depicting TPA are shifted towards slightly to higher angles in Cs-TPA ${ }^{23}$.

Fourier transform-infrared spectroscopy analysis (FT-IR) Cs-TPAs was characterized by using FT-IR to investigate structure of catalysts. The results are shown in Fig. 2.

Basic structure of synthesized Cs-TPAs were explained by comparing its absorbance with that of TPA using FT-IR analysis. FT-IR bands of pure TPA (Fig. 3), have six characteristic peaks of Keggin structure observed at $1080 \mathrm{~cm}^{-1}(\mathrm{P}-\mathrm{O}$ in central tetrahedral), $990 \mathrm{~cm}^{-1}\left(\mathrm{~W}=\mathrm{O}_{\mathrm{f}}\right.$ terminal oxygen in the Keggin structure), 882 and $804 \mathrm{~cm}^{-1}\left(\mathrm{~W}-\mathrm{O}_{\mathrm{c}}-\mathrm{W}\right), 582$ and $516 \mathrm{~cm}^{-1}$, which coincides with those referred in the literature ${ }^{22,24-27}$. The FT-IR spectrum of Cs-TPA salt exhibits similar characteristic bands compared with that of pure TPA. It was also that all Cs-TPAs have very similar FT-IR bands with each other. However, the typical vibration of the $\mathrm{W}=\mathrm{O}_{\mathrm{f}}=990 \mathrm{~cm}^{-1}$ in TPA is shifted to $985 \mathrm{~cm}^{-1}$ in Cs-TPA. This shift shows the interaction between $\mathrm{Cs}^{+}$and $\mathrm{W}=\mathrm{O}^{23}$.

Scanning electron microscopy (SEM): Because of the similarity of the samples, the surface morphology of Cs-TPA coded by $01 \mathrm{G} 50 \mathrm{~V}$ and $1 \mathrm{G} 50 \mathrm{~V}$ are only given in Fig. 3. The other synthesized Cs-TPA have similar SEM images. In the images, it is seen that Cs-TPA are having irregular shape with well-defined crystalline particles. These observations are in accordance with literature ${ }^{11,28-30}$.

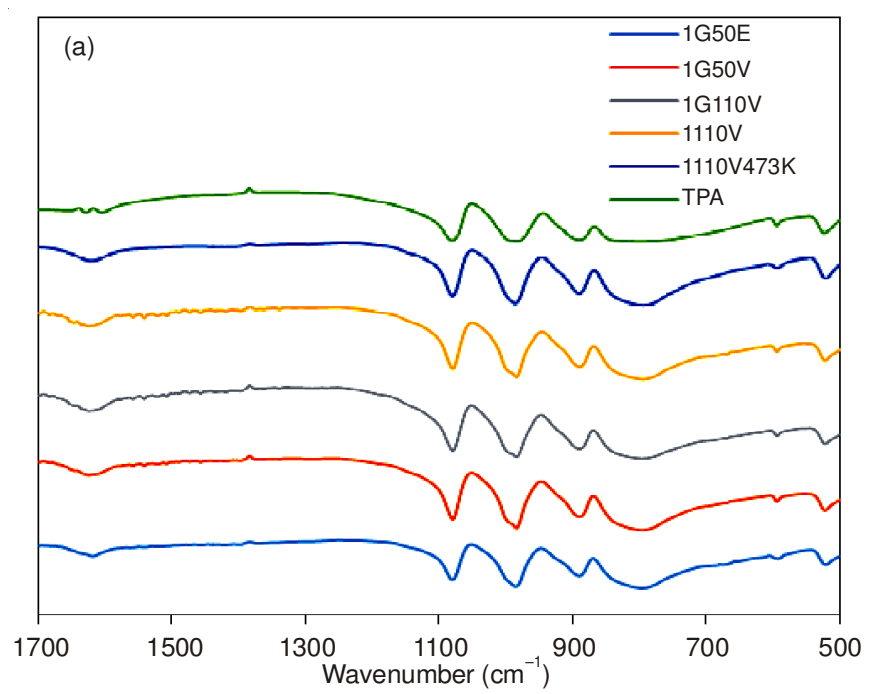

Particle size distribution and crystallite size: A laser diffraction technique afforded the size of the all synthesized Cs-TPA. The particle size distribution of Cs-TPA dispersed in water is shown in Fig. 4. The particles size varies between 40 to $450 \mathrm{~nm}$. Average particle size for all Cs-TPA are124 and $112 \mathrm{~nm}$ for synthesized catalysts with 0.1 and $1 \mathrm{~mL} / \mathrm{min}$ addition rate of $\mathrm{Cs}_{2} \mathrm{CO}_{3}$ solution to TPA solution, respectively.

The crystallite sizes of all synthesized Cs-TPA were obtained by using Scherrer's equation using XRD data from Fig. $1 . D=k \lambda / \beta \cos \theta$ where $D$ is crystallite size, $\lambda$ is the radiation wavelength (1.5406 $\AA$ ), $\beta$ is the peak full width at half maximum (FWHM), $\theta$ is the diffracting angle and $\mathrm{k}=$ 0.90 for spherical shape particle. It was found that the average crystallite size of all synthesized Cs-TPA is approximately the same and average value of it is to be $12.54 \mathrm{~nm}$.

Thermal gravimetric analysis: The thermal analyses have been carried out on all synthesized Cs-TPA and TPA. The results of these analyses are shown in Fig. 5. The TG and DTG curves of 12-tungstophosphoric acid show a weight loss of about $4 \%$ up to a temperature of $300{ }^{\circ} \mathrm{C}$, indicating loss of free and adsorbed water. The gradual weight loss of about $1 \%$ up to $700{ }^{\circ} \mathrm{C}$ corresponds to the mass loss due to the reaction between acidic protons and structural oxygen from 12tungstophosphoric acid, releasing water, followed by decomposition to $\mathrm{WO}_{3}$ and $\mathrm{POx}$ species ${ }^{31}$. All synthesized CsTPA showed a weight loss below $200{ }^{\circ} \mathrm{C}$, indicating loss of free and adsorbed water. Between temperature of $200-900{ }^{\circ} \mathrm{C}$, there is no weight loss of Cs-TPA because of its chemical

Fig. 2. FT-IR spectrums for (a) synthesized catalysts with $1 \mathrm{~mL} / \mathrm{min}$ addition rate (b) synthesized catalysts with $0.1 \mathrm{~mL} / \mathrm{min}$ addition rate
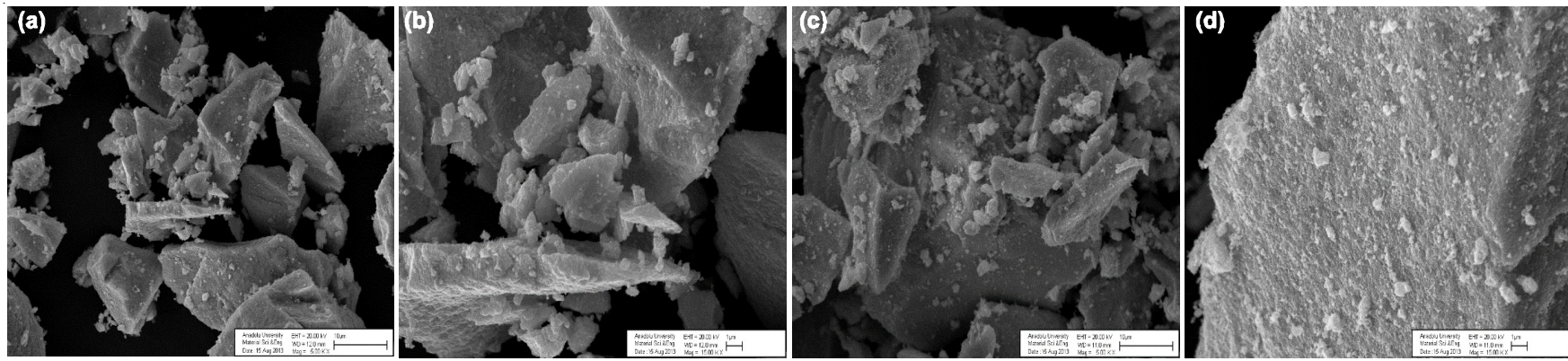

Fig. 3. SEM images of (a) and (b) synthesized catalysts with $1 \mathrm{~mL} / \mathrm{min}$ addition rate (c) and (d) synthesized catalysts with $0.1 \mathrm{~mL} / \mathrm{min}$ addition rate at $5 \mathrm{KX}$ and $15 \mathrm{KX}$, respectively

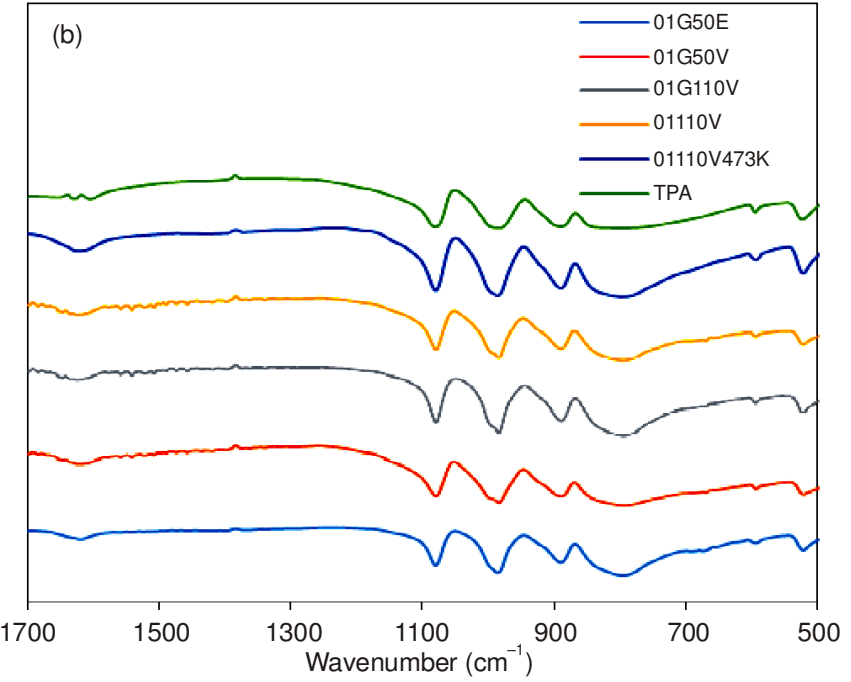

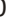



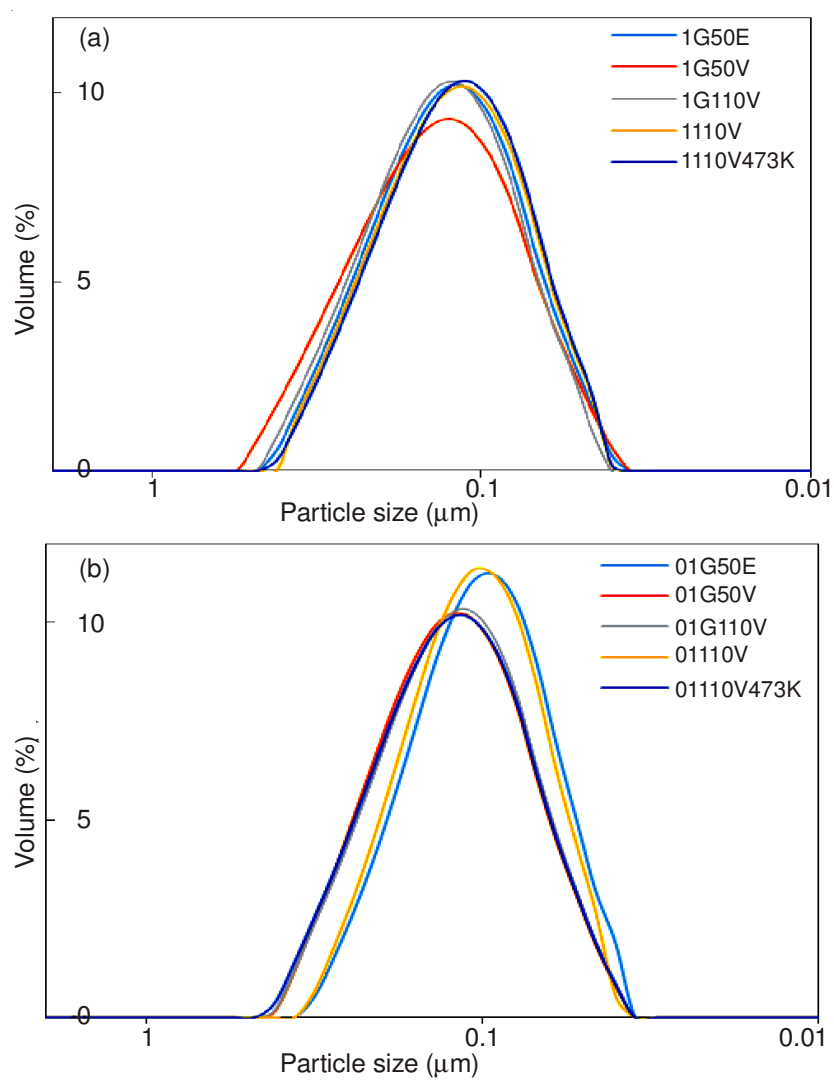

Fig. 4. Particle size distribution for (a) synthesized catalysts with $1 \mathrm{~mL} / \mathrm{min}$ addition rate (b) synthesized catalysts with $0.1 \mathrm{~mL} / \mathrm{min}$ addition rate

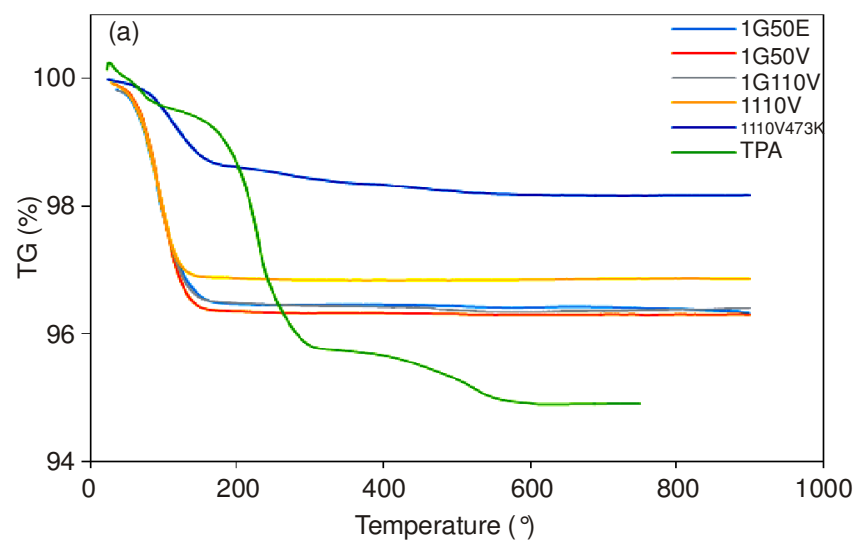

Temperature $\left({ }^{\circ}\right)$

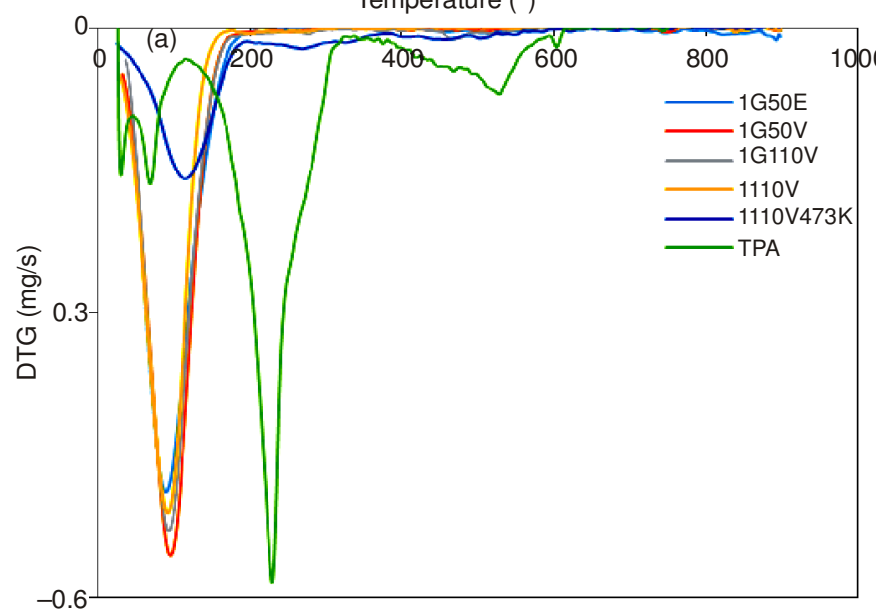

stability. This chemical stability show that all Cs-TPA was synthesized successfully ${ }^{23}$.

$\mathbf{N}_{2}$ adsorption/desorption analysis: Single and multipoint BET are as, average pore diameters and pore volumes are determinedby $\mathrm{N}_{2}$ adsorption analysis. The results are given in Table-2.

\begin{tabular}{|c|c|c|c|c|c|}
\hline \multicolumn{6}{|c|}{ TABLE-2 } \\
\hline \multirow[b]{2}{*}{ Sample name } & \multicolumn{3}{|c|}{ Surface area $\left(\mathrm{m}^{2} / \mathrm{g}\right)$} & \multirow[b]{2}{*}{$\begin{array}{c}\text { Pore } \\
\text { Diameter, } \\
\mathrm{d}_{\mathrm{BJH}}(\AA)\end{array}$} & \multirow[b]{2}{*}{$\begin{array}{c}\text { Pore } \\
\text { Volume, } \\
\mathrm{V}_{\text {ВJH }}\left(\mathrm{cm}^{3} / \mathrm{g}\right)\end{array}$} \\
\hline & $\begin{array}{c}\text { BET } \\
\text { (multi } \\
\text { point) }\end{array}$ & $\begin{array}{c}\text { BET } \\
\text { (single } \\
\text { point) }\end{array}$ & $\mathrm{S}_{\mathrm{BJH}}$ & & \\
\hline $1 \mathrm{G} 50 \mathrm{E}$ & 88.739 & 143.399 & 95.983 & 40.961 & 0.09829 \\
\hline 01G50E & 93.482 & 140.106 & 98.523 & 45.651 & 0.11244 \\
\hline $1 \mathrm{G} 50 \mathrm{~V}$ & 90.644 & 147.895 & 94.975 & 48.307 & 0.11469 \\
\hline $01 \mathrm{G} 50 \mathrm{~V}$ & 96.801 & 148.538 & 102.054 & 40.013 & 0.10208 \\
\hline $1 \mathrm{G} 110 \mathrm{~V}$ & 91.641 & 147.005 & 99.964 & 42.236 & 0.105552 \\
\hline 01G110V & 87.850 & 137.023 & 93.640 & 51.998 & 0.12172 \\
\hline $1110 \mathrm{~V}$ & 87.685 & 145.033 & 95.307 & 57.351 & 0.13665 \\
\hline 01110V & 85.716 & 133.344 & 96.125 & 39.212 & 0.09423 \\
\hline $1110 \mathrm{~V} 473 \mathrm{~K}$ & 86.401 & 142.792 & 94.750 & 42.739 & 0.10123 \\
\hline 01110V473K & 91.918 & 140.328 & 99.613 & 39.449 & 0.09824 \\
\hline
\end{tabular}

It is seen in Table- 2 that surface areas, pore volume, average pore diameter of Cs-TPAs obtained by different synthesis conditions have different values. It is concluded that different synthesis conditions such as the aging, atmospheric dryingvacuum drying and calcination, addition rate of $\mathrm{Cs}_{2} \mathrm{CO}_{3}$ solution to TPA solution effectedthe surface area and porosity. Applying vacuum drying in synthesizing of Cs-TPA, BET areas
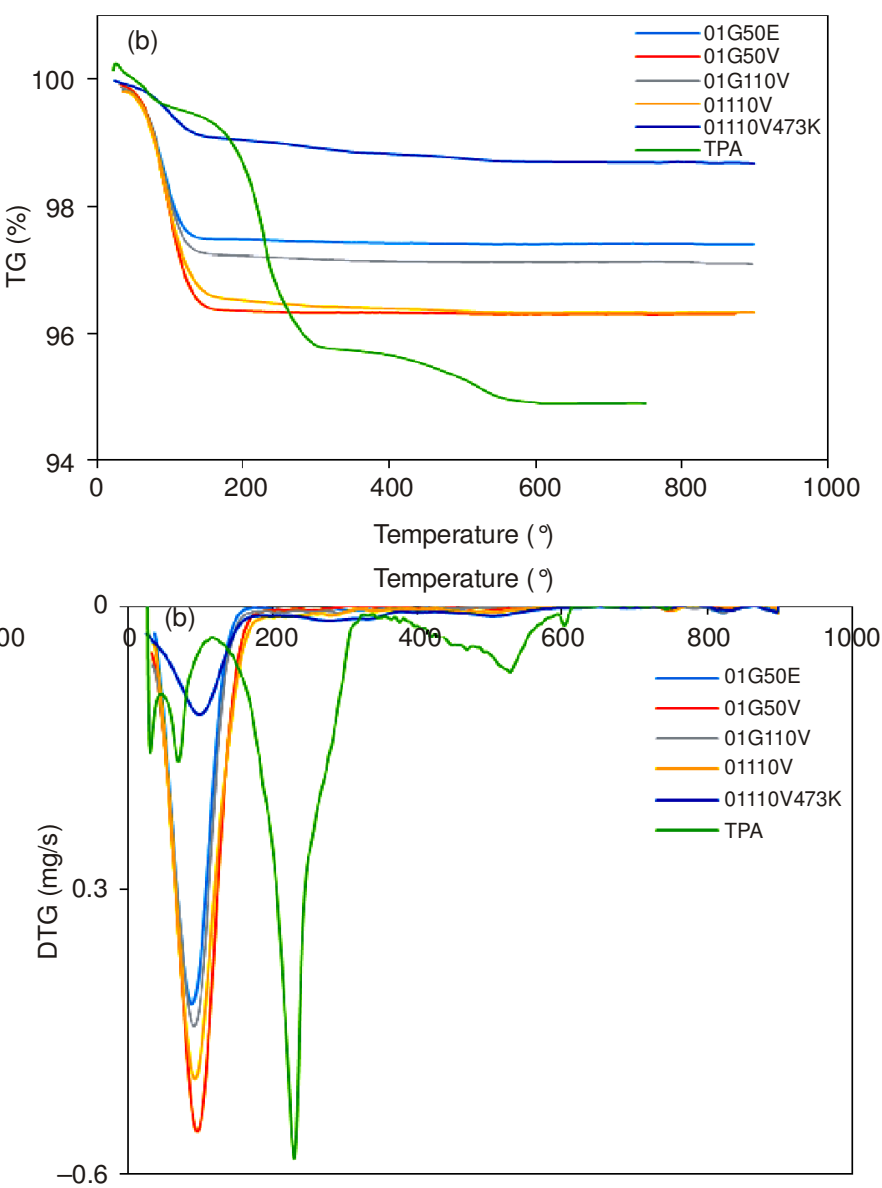

Fig. 5. TG and DTG curves of (a) synthesized catalysts with $1 \mathrm{~mL} / \mathrm{min}$ addition rate (b) synthesized catalysts with $0.1 \mathrm{~mL} / \mathrm{min}$ addition rate, respectively 

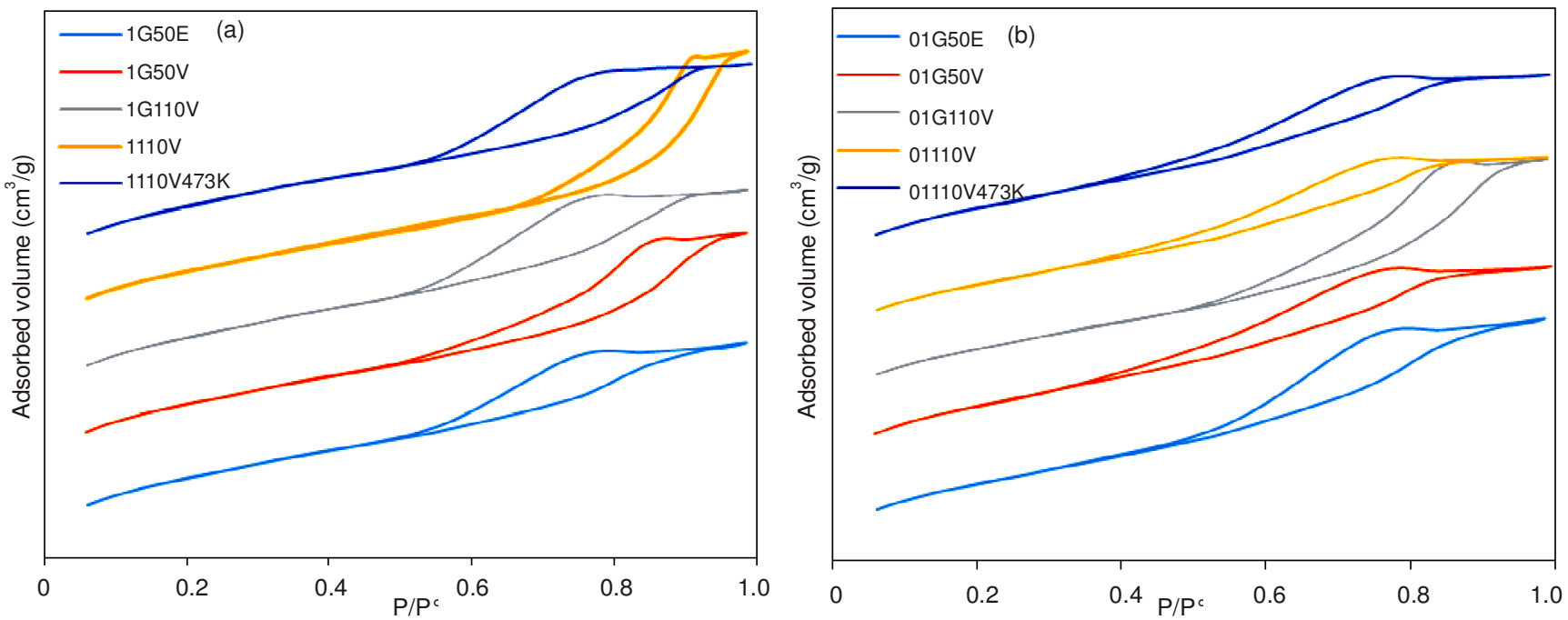

Fig. 6. $\mathrm{N}_{2}$ adsorption/desorption isotherms of synthesized CS-TPAs (a) synthesized catalysts with $1 \mathrm{~mL} / \mathrm{min}$ addition rate (b) synthesized catalysts with 0.1 $\mathrm{mL} / \mathrm{min}$ addition rate
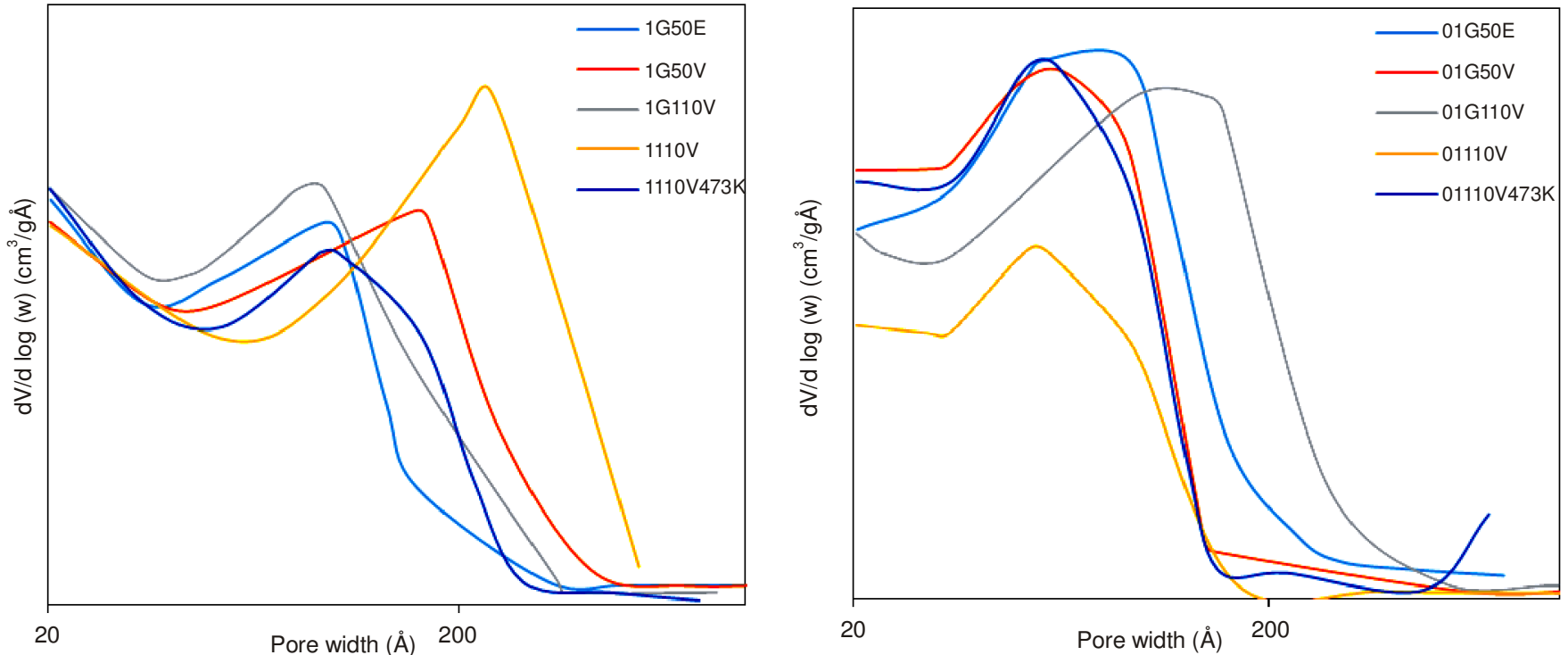

Fig. 7. Pore size distribution plot (a) synthesized catalysts with $1 \mathrm{~mL} / \mathrm{min}$ addition rate (b) synthesized catalysts with $0.1 \mathrm{~mL} / \mathrm{min}$ addition rate

and average pore diameters are increased. In the increasing of vacuum drying temperature, BET areas is nearly same but average pore diameters are decreased. The aging, decreases BET areas but increases average pore diameter. Also it is observed that calcination, increases BET areas but decreases average pore diameter. Generally in all methods, increasing the addition rate of $\mathrm{Cs}_{2} \mathrm{CO}_{3}$ solution to the TPA solution increases BET areas but decreases average pore diameter. The sample coded by $01 \mathrm{G} 50 \mathrm{~V}$ showed the highest surface area with 4.5 $\mathrm{nm}$ pore diameter among all synthesized Cs-TPA.

Effect of each methods on the nitrogen adsorptiondesorption isotherms of the all synthesized CS-TPAs are shown in Fig. 6. All synthesized Cs-TPA shows a Type-IV isotherm in which $\mathrm{H}_{2}$ hysteresis loops was observed ${ }^{32}$. The Type IV isotherm is usually observed for materials having mesopores ${ }^{9}$.

The pore-size distribution curves shown in Fig. 7 exhibits peaks at around $7 \mathrm{~nm}$ of pore radius for catalysts obtained at addition rate of $0.1 \mathrm{~mL} / \mathrm{min}$ and $11 \mathrm{~nm}$ for catalysts obtained at addition rate of $1 \mathrm{~mL} / \mathrm{min}$. Although pore radius of addition rate of $1 \mathrm{~mL} / \mathrm{min}$ is higher than that of addition rate of 0.1
$\mathrm{mL} / \mathrm{min}$. However micro porosity increases with increasing addition rate.

\section{Conclusions}

In this study, the methods published in the literature were modified by monitoring the aging, atmospheric drying-vacuum drying and calcination to enhance the surface properties such as the surface area and porosity was investigated. The characterization of the synthesized Cs-TPA were examined by the XRD, FTIR, SEM, TG-DTG, particle distribution and crystallite size. The results show that there is no significant differ-ence between synthesis methods of all Cs-TPA's. However, $\mathrm{N}_{2}$ adsorption/desorption isotherms shows some differences in surface properties of Cs-TPA depending on the synthesizing methods. Generally in each methods, BET surface area is decreasing with the increasing addition rate of the solutions and pore radius is vice versa. The sample coded by 01G50V showed the highest surface areawith $4.5 \mathrm{~nm}$ pore diameter among the all synthesized Cs-TPA. 


\section{ACKNOWLEDGEMENTS}

The authors thank Anadolu University Scientific Research Projects Commission (Project No: 1207F112) for the financial support.

\section{REFERENCES}

1. I.V. Kozhevnikov, Catal. Rev., Sci. Eng., 37, 311 (1995).

2. E. Papaconstantinou, Chem. Soc. Rev., 18, 1 (1989).

3. L.E. Briand, G.T. Baronetti and H.J. Thomas, Appl. Catal. A, 256, 37 (2003).

4. I.V. Kozhevnikov, Chem. Rev., 98, 171 (1998).

5. T. Okuhara, N. Mizuno and M. Misono, Appl. Catal. A, 222, 63 (2001).

6. K. Na, T. Okuhara and M. Misono, J. Chem. Soc., Faraday Trans., 91 , 367 (1995).

7. N. Essayem, G. Coudurier, M. Fournier and J.C. Védrine, Catal. Lett., 34, 223 (1995).

8. T. Okuhara, T. Nishimura, H. Watanabe and M. Misono, J. Mol. Catal., 74, 247 (1992)

9. T. Okuhara, T. Nishimura and M. Misono, Stud. Surf. Sci. Catal., 101, 581 (1996).

10. M. Kimura, T. Nakato and T. Okuhara, Appl. Catal. A, 165, 227 (1997).

11. T. Okuhara, H. Watanabe, T. Nishimura, K. Inumaru and M. Misono, Chem. Mater., 12, 2230 (2000)

12. J.A. Dias, E. Caliman and S.C. Loureiro Dias, Micropor. Mesopor. Mater., 76, 221 (2004)

13. T. Okuhara, T. Nishimura, H. Watanabe and M. Misono, J. Mol. Catal., 74, 247 (1992).

14. T. Nishimura, T. Okuhara and M. Misono, Appl. Catal., 73, L7 (1991).

15. K. Na, T. Okuhara and M. Misono, J. Chem. Soc., Faraday Trans. I, 91, 367 (1995)
16. N. Essayem, G. Coudurier, M. Fournier and J.C. Vedrine, Catal. Lett., 34, 223 (1995).

17. K. Na, T. Iizaki, T. Okuhara and M. Misono, J. Mol. Catal. Chem., 115, 449 (1997).

18. M. Kimura, T. Nakato and T. Okuhara, Appl. Catal. A, 165, 227 (1997).

19. T. Okuhara, M. Kimura and T. Nakato, Chem. Lett., 839 (1997).

20. K. Narasimharao, D.R. Brown, A.F. Lee, A.D. Newman, P.F. Siril, S.J. Tavener and K. Wilson, J. Catal., 248, 226 (2007).

21. G.G. Volkova, L.M. Plyasova, A.N. Salanov, G.N. Kustova, T.M. Yurieva and V.A. Likholobov, Catal. Lett., 80, 175 (2002).

22. J.A. Dias, E. Caliman and S.C. Loureiro Dias, Micropor. Mesopor. Mater., 76, 221 (2004).

23. H. Dogan, T.Y. Inan, E. Unveren and M. Kaya, Int. J. Hydrogen Energy, 35, 7784 (2010).

24. S. Choi, Y. Wang, Z. Nie, J. Liu and C.H.F. Peden, Catal. Today, 55, 117 (2000)

25. N. Essayem, A. Holmqvist, P.Y. Gayraud, J.C. Vedrine and T.Y. Ben, J. Catal., 197, 273 (2001).

26. D. Zhao, B.L. Yi, H.M. Zhang, H.M. Yu, L. Wang, Y.W. Ma and D.M. Xing, J. Power Sources, 190, 301 (2009).

27. A. Ghanbari-Siahkali, A. Philippou, J. Dwyer and M.W. Anderson, Appl. Catal. A., 19, 57 (2000).

28. H.Y. Shin, S.H. An, R. Sheikh, Y.H. Park and S.Y. Bae, Fuel, 96, 572 (2012).

29. P. Madhusudhan Rao, M.V. Landau, A. Wolfson, A.M. Shapira-Tchelet and M. Herskowitz, Micropor. Mesopor. Mater., 80, 43 (2005).

30. S.W. Chuang, S.L.C. Hsu and M.L. Yang, Eur. Polym. J., 44, 2202 (2008).

31. S.K. Bhorodwaj and D.K. Dutta, Appl. Catal. A, 378, 221 (2010).

32. T. Nakato, Y. Toyoshi, M. Kimura and T. Okuhara, Catal. Today, 52, 23 (1999). 